\title{
Chapter 4 \\ Same-Sex Parents Negotiating the Law in Italy: Between Claims of Recognition and Practices of Exclusion
}

\author{
Marina Franchi and Giulia Selmi
}

\begin{abstract}
Italy represents a particular case in the panorama of Southern Europe; it is going through a very crucial moment when issues of sexual politics are at the forefront of the political and societal debate. Against the backdrop of the plurality of ways in which individuals arrange their intimate lives, the increased visibility in the public and political sphere of LGBT issues, and the de-traditionalisation of gendered relations, we are witnessing a strong, at times violent heterosexist/conservative backlash. Against this background LGB individuals organise their intimate lives, make reproductive choices and develop strategies to protect themselves and their most vulnerable next of kin. Drawing on qualitative interviews with gay and lesbian couples in Italy this chapter aims to investigate the intersection between the context and the ways in which individuals in same-sex relationships organise their intimate lives. It highlights the impact of the law and the socio-cultural context on the intimate choices of individuals, but also contribute to the growing body of literature that complicates the assimilation/disruption dyad and caution against the translatability of notions of heteronormativity and homonormativity.
\end{abstract}

Keywords Intimate citizenship · Norms · Parenting $\cdot$ Heteronormativity · Familism

\author{
M. Franchi \\ London School of Economics, London, UK \\ e-mail: m.franchi@1se.ac.uk \\ G. Selmi ( $\square)$ \\ University of Verona, Verona, Italy \\ e-mail: giulia.selmi@univr.it
}




\subsection{Introduction}

Familism and family matters are profoundly conservative cultural constructs that came to represent an internationally renowned trait of Italian culture. The centrality of the family has been incorporated into the Italian welfare regime where access to services and support, predicated on legally recognised kinship relationships, can be restricted to those who form care and support networks that are not legally recognized as family. Public and political discourses are occupied by a notion of the natural family fostered by Catholic Ideology and defended by political parties across the spectrum. Against this background, subsequent governments since the early 2000s routinely failed to approve laws that would provide legal recognition to same-sex unions. Only in February 2016, the Italian Senate approved the Cirinnà bill by an overwhelming majority. The law however excluded parents with no biological ties with their children from any recognition of parenting rights.

Such provision would have granted legal recognition to parents with no biological ties with their children. Within this scenario, LGBT individuals routinely negotiate the absence of legal recognition of their family, a task that becomes particularly costly in relation to parenting, since social parents are legally and socially invisible. Drawing on 29 in-depth interviews carried out with gay men and lesbian women aged between 20 and 60 years-old in five urban centres in Italy, this chapter analyses how respondents account for their experiences of parenting and analyses the practices enacted to be recognized as a family. In the context of the tensions that characterise contemporary Italy such practises carry a hefty symbolic and material costs. Does the absence of norms is conducive to opening a space for queering the family heteronormative ideal? Or, on the contrary, this void forces gay and lesbian couples to perform the heteronormative script in order to fully access citizenship rights?

\subsection{The Long (and Incomplete) Road to Equality: LGBT Rights in the Italian Context}

In order to make sense of the narratives that are analysed in the following sections, here we delineate the background against which the interviews have been collected, and sketch the social and legislative status quo that affected the interviewees' experiences. At the moment of conducting the interviews the Italian legislative system was still lacking any legal recognition for forms of unions other than heterosexual marriage and any law aimed at tackling homophobic violence, despite the continuous warnings of the European Union and the pressure of many groups and LGBT rights advocates. Approving a law has been, for subsequent governments since the years 2000s, a challenging political endeavour. During the Prodi II Government (2006-2008) two different bills reached the parliamentary vote in less than 6 months; the DICO bill (February 2007) and the CUS bill (July 2007). Both bills were supposed to regulate the relationship between two cohabiting adults. 
Both bills have been fiercely opposed by conservative politicians and religious hierarchies that perceived the legal recognition of same-sex couples as a threat to the 'natural family'. LGBT advocates, on the other hand, criticised both bills for being a weak recognition of rights. Both texts, in fact, posed serious constraints to the legal effects of the partnership they aimed to regulate, in order to emphasise its status as different from marriage. Neither the DICO bill nor the CUS bill ever became laws. For a long time after the demise of the Prodi II Government, the issue of de facto unions was kept off the political agenda. In September 2008, Berlusconi's government drafted a bill entitled Disciplina dei diritti e dei doveri di reciprocità dei conviventi (DidoRe - 'Regulation of the rights and duties of reciprocity on the part of cohabitees'). The bill never passed the barrier of the Justice Commission of the Chambers of Deputies (Donà 2009: 343-344). Following the resignation of Berlusconi in 2011, the issue of the facto unions was again pushed out of the political agenda. Whilst it being a very contentious topic across parties, sexual citizenship rights were often framed as dangerous to the stability of governments as well as less of a priority in view of the ongoing economic crisis (Crowhurst and Bertone 2012: 416). The Renzi administration, supported by a very diverse coalition of parties, in power from February 2014 to December 2016, had been willing to reopen the discussion. Only in March 2015 the Justice Commission of the Senate reached a final agreement on a text on civil unions (the so-called Cirinnà bill, named after the first signer) aiming at legally recognising same-sex couples. The bill has been approved in May 2016 and finally became law.

The approval of the Cirinnà law has been defined by some as a milestone in the legal recognition of LGB couples in Italy. Others, however, define it as a watereddown recognition of rights (Mancina and Vassallo 2016), that emerged from a set of compromises within different groups of the Government majority. A central point of contention has been the legal recognition of parenting rights. In its original version the bill incorporated a provision that would allow social parents to be legally recognised. Right before the vote at the Senate, however, on February 26th following the Five Star Movement's withdrawal of support, the Prime Minister Renzi stripped the step-child adoption from the bill allegedly as a move to gain a solid majority and grant its full approval. The provision would have granted the right to adopt the children of one's partner to LG partners legally recognised under the new law. During the months that preceded the approval of the Cirinnà Law same-sex parenting rights became the forefront of the political and societal debate.

Public spaces were increasingly occupied by conservative Catholic Associations such as the Sentinelle in Piedi (Standing Sentinels) arguing that the recognition of same-sex couples and in particular their parenting rights was a threat against a 'natural order' (Garbagnoli 2014) that was particularly threatened by the 'marketisation of life' in relation to surrogacy. The debate was punctuated by references to biology, blood ties and the 'natural family' (Lasio and Serri 2017) hence reaffirming heterosexuality as the one and only prerequisite to (good) parenting. Societal anxiety around non-heterosexual parenting is not restricted to the Italian context (see also Butler 2002, Fassin 2001) and it is often evoked through the discursive trope of the wellbeing of the child that is constructed as impaired by the lack of complementary gender roles (Saraceno 2012). 
At the core of these groups' protests was a fierce attack to what they termed l'ideologia del gender (the ideology of gender) and la teoria del gender (the theory of gender) an umbrella term defining any feminist and LGBTQ claim ranging from anti-bulling and anti-discrimination educational programs to gender equality and reproductive rights (Selmi 2015, Garbagnoli and Prearo 2018). Their argument is informed by a determinist understanding of gender, sexuality and family. Antidiscrimination policies are here understood as tools for undermining the primacy of heterosexuality as the premise for full citizenship rights.

Such a premise is also protected by a relentless opposition to any bill recognising homophobia as an aggravating circumstance in hate crimes. Conservative groups and part of the Catholic Church denounced any attempts to legislate against homophobic hate crimes as acts against free speech and frame them as attacks on the Catholic Church itself and on far right-wing groups and parties. Subsequent drafts have also been strongly criticised by representatives of LGBT groups, who questioned their efficacy in tackling institutional homophobia and the impunity of politicians and religious representatives. In particular, a draft presented in 2013 included an amendment proposed by Gregorio Gitti (PD-Partito Democratico) which stated that the definition of hate speech cannot be applied to opinions expressed within political parties or religious, cultural, and educational institutions de facto emptying the bill of its transformative power.

In opposition to the actions of a conservative part of the Italian society, local and regional governments have been at the forefront of implementing inclusive, nondiscriminatory good practice, as well as creating a space for action and advocacy, especially at the time of collecting the interviews. For instance, local government created registries that granted some recognition to forms of unions in the form of cohabitation registries, way before the approval of the Cirinnà law in 2016. In over a hundred local governments in Italy, such registries were open to both heterosexual and same-sex couples and granted access to housing benefits and locally regulated services such as childcare and health care. While these provisions had no effect at the national level and outside the borders of the constituencies, municipalities and regional governments have been central to fostering cultural change that contributed to the creation of the conditions for the national law to be approved.

Following the approval of the Cirinnà law local authorities have been playing a particularly crucial role in the battle for the recognition of parental rights. The majors of many cities (i.e. Turin, Bologna, Milan, Palermo, Naples, etc.) are transcribing the birth certificates of the children born abroad by same sex parents; and since 2018 they are re-issuing the birth certificate of children born in Italy from same sex couples adding the name of the parent without biological bonds with the child in order to grant them full rights. Together with a series of rulings on stepchild adoption issued by several juvenile courts since 2014 (Farina 2017), local authorities are playing a key role in filling the equality gap between straight and same-sex parents and in fostering change toward the full recognition of sexual citizenship rights to LGBT couples and individuals.

Italy, then, appears to be characterised by an ambivalent attitude toward LGBT rights (Trappolin 2009): on one hand, public attitudes towards LGBT families and 
couples are changing (ISTAT 2012), on the other, the inclination towards denial of LGBT experiences (Bertone 2009a) is still persistent, and non-heterosexual life are routinely marginalised. In this context the legal recognition of sexual rights keeps being a difficult and tortuous path.

\subsection{The Discrete Scent of 'Family': Changes and Resistance to a Social Model}

The Italian public sphere is characterised by a peculiar resistance to "allowing discursive space even for a homonormative (Duggan 2003), familialised subject, despite the attempts made in this direction by LGBT movements" (Bertone and Gusmano 2013: 261-262). It is against this context that normativity and resistance become blurred concepts that need to be carefully unravelled. In a scenario were LGBT families are increasingly participating in public debates and claiming recognition from the State, marriage and the family appear to retain the high symbolic value that has characterised Italy's modernity (Rosina and Viazzo 2008; Ruspini 2005), and the hegemonic norm of the nuclear family remains incredibly strong (Ruspini 2009; Bertone 2009b).

In the context of Italy as elsewhere, claims for recognition of partnership, parenting and inclusion in the welfare state can be interpreted as having the power to produce and transform circulating meanings regarding family, sexuality, kinship and rights (Plummer 2003). The shift of discourses and practices from the political margins to the centre has often been defined as destabilising and potentially generative of new meanings. In particular in the West, the claims for recognition of the LGBT movements in the past decades has been interpreted as reconfiguring notion of belonging to the community of citizens (Weeks et al. 2001; Weeks 1998).

However, the claims for legally recognised relationships and parenting rights have also been interpreted as overlooking the normalising power of state recognition (Butler 2002). In the recognition of relationship and parental rights, it has been argued, lies the exclusion of forms of parenting and relationships that evade the monogamous, dyadic family form. The recognition of lesbian and gay rights has hence been interpreted as revealing how, while heterosexuality might in specific instances no longer be a sine qua non requirement for the recognition of rights, "heterosexuality has not yet been displaced as the reference point for "equality" and "normality" "but is maintained as the norm that polices the boundaries of belonging and exclusion (Richardson and Monro 2012: 65).

A similar tension with regard to the normalising power of individuals' context can also be traced in the sociological theories of late modernity. Within a sociological framework, theories of de-traditionalisation and transformations of intimacies such as Giddens' (1992), and Beck and Beck-Gernsheim's (1995), explored how interpersonal exchanges and kin formation develops in contemporary society once the functionalist traditional model declined and produced a "wholesale democratization of the interpersonal domain" (Giddens 1992: 3). Within this frame, great 
emphasis is placed on the way in which late modernity is characterised by a displacement of traditional ties and an emphasis on individual choice thus fundamentally reshaping the societal landscape (Beck and Beck-Gernsheim 1995; Giddens 1992).

This post - familial family (Beck-Gernsheim 1998: 70) is constructed around elective ties and it is understood as creative and self-determined both in terms of the constitution of kin networks and of emotional and relationship rules. Relationships therefore are imagined here free from societal and structural constraints and individuals are thought as able to negotiate their needs and desire free from power relationships. In this understanding, gay men and lesbian women have been defined as pioneers of 'pure relationships', which individuals enter on equal terms and which might end when those individuals' needs are no longer met (Giddens 1992).

These understandings have been met with scepticism by many scholars (Gabb 2008). In fact such theories appear to not take into due consideration how gendered politics of care continue to generate constraints (Skeggs 2004). Further, they do not account for the ways in which gender (Jamieson 1998) class (Skeggs 2004) sexuality and ethnicity (Hey 2005) place ongoing constraints on the possibilities of the self as a 'reflexive project'. At the level of the analysis of norms, it is also important not to overlook the hegemonic power of the ideal of the monogamous, generative couple sustained by the ideal notion of romantic love. Theories of detraditionalisation and individualisation also keep the couple (even if democratic, dialogic and equal) as the main reference for the development of an intimate life project. As Gross argues the couple is still a 'guiding cultural ideal' that permeates much of the Western societies. As such it invests also those LGBT communities that while in opposition with the heteronormative model still cannot escape it. As a normative ideal it remains a point of departure for any relationship narrative where the couple is the only suitable, desirable, thinkable project. In unveiling the hegemonic hold of the ideal of the couple in Contemporary America, Gross not only questions the potential of de-traditionalisation but also highlights the resilience of patriarchal beliefs and practices (Gross 2005: 297-301). As Gabb (2008) points out, families remain the norm of the structural framework of our private lives. The increasingly visible LGBT families "rather than destabilizing normative models testify the power of familial ideology in representing the family as the best ways to live our lives" (2008: 16). Families are therefore expected to conform to a two-parents model that remains the condition for recognition of same-sex parenting (Roseneil et al. 2013: 18).

It is however always necessary to take into consideration that normative power and destabilising forces are always dependent on the context. Roisin Ryan-Flood in her work on lesbian motherhood explores the reproductive choices among lesbian women in Sweden and in Ireland (2005). She argues that the "way in which lesbian parents in the two countries reinvent and reinscribe prevailing discourses of the family according to their own situatedness as social and cultural actors highlights the significance of context to understandings of lesbian parent experiences, possibilities, and constraints" (2005:190). In so doing Ryan-Flood warns about the crucial role structural constraints and societal values play in shaping the very definition of normative/hegemonic and disruptive power (2005). 


\subsection{Methodology and Sample}

In this paper, we draw on 29 in-depth interviews focusing on the daily life experiences of gay and lesbian couples and parents. We conducted the interviews between October 2014 and 2015 before the Cirinnà law was approved with gay men and lesbian women that described themselves as in a long-term relationship. Twentytwo were individual interviews with one member of the couple, while seven were performed with both members.

Three cities in the Centre-North and three cities in the Centre-South were selected to carry out the research. Alongside the socio-cultural differences in terms of family values and ties between north and south, the six urban contexts where selected due to their different features in terms of local policies on LGBT families and individuals inclusion (i.e. city register of same-sex partnership, policies against discrimination, etc.) and the different degrees of relevance of the local LGBT movements (i.e. number of associations, advocacy programmes with the local government, etc.). The spectrum of policies represented in our sample, allowed to gather different life experiences in relation to the social context individuals live in. Within these six cities, participants were selected through a snowball sampling technique thanks both to personal contacts and the network of Italian LGBT associations that were asked for support to recruit participants.

On the whole we interviewed 13 men and 22 women. The youngest respondent in the group was 22 years old, while the oldest was 62 . While we aimed to have an even distribution in term of age, in the sample those who are around or over 40 years old are overrepresented. This is a direct consequence of the focus of the research that aimed at collecting stories of people dealing with family issues (housing, planning parenthood, childcare, elderly care, etcetera) and hence conditioned the age of the participants. For instance, in Italy the average age when one becomes a parent is higher than the rest of Europe, and more so for people in a same-sex relationship.

At the time of the interviews, thirteen participants were parents or were expecting a child, while two were going through ART in order to conceive. Seven women had (or were having) children within a same-sex relationship (six through ART and one through self-insemination), while three women had children conceived while in a previous heterosexual relationship. Two men had children while in a previous heterosexual relationship, one gay couple had children through surrogacy and another one was fostering.

Interviews lasted on average between 1 hour and 1.5 hours and were transcribed verbatim. The interview script began with a generative question on the couple/family story in order to encourage the participants' storytelling (Riessman 2008). Then ad hoc questions were added to encourage further discussion about processes of visibility and identity negotiation in the circle of family and acquaintances as well as in the social context. We included also questions on the encounter with the public sphere (i.e. public services, institutions); and our informants' experiences of discrimination and homophobia. For the purpose of this chapter, we will draw particularly on the interviews collected with parents or prospective parents. The reason is 
twofold: first, the legal situation of same sex parents has not changed after the approval of the Cirinnà law, therefore the narratives we collected back then still mirror the actual challenges of gay and lesbian parents and their children; second, same-sex parenting epitomizes the tensions between the on-going change in family and kinship configurations and the endurance of heteronormative family models (Bertone 2015).

\subsection{Navigating Heteronormativity in Contemporary Italy}

One key feature of narratives is the uniqueness and the peculiarity of each story that refers to a specific subject in a situated context (Bruner 1996). However, even if every story is unique and peculiar, personal narratives are performed through and in relation to public narratives (Somers and Gibson 1994) or cultural repertoires. Social actors can embrace or challenge such tropes by contributing to their transformation and the construction of new stories (Plummer 1995). While heteronormativity is a "fundamental organizing principle throughout the social order" (Green [2002, 521], quoted in Gamson and Moon [2004, 48]), it is also the social and symbolic repertoire available to individuals to shape both their subjectivities and their public identities (Rosenfeld 2009). The analysis of the narratives collected therefore can open up a space for understanding how heteronormative discourses "are both subverted and reinscribed" (Ryan-Flood 2005: 201). We will explore the interviews collected first to grasp how and to what extent these narratives challenge or queer the notion of couple and family; second to explore the relationship between these narratives and the specific societal and legal Italian context.

\subsubsection{Forcing the Boundaries of Heteronormative Kinship}

As Ahmed points out on her notion of discomfort of queer families and couples, the point is "not about assimilation or resistance, but about inhabiting norms differently" (Ahmed 2004: 155). Some of our respondents' stories offer a space for redefining or, better, for forcing the boundaries of heteronormativity and for building new meanings able to account for their specific experiences. In doing so they challenge the notion of family trying to carve out space for their experiences (Franchi and Selmi 2018). In the accounts of some respondents the notions of coupledom, family and kinship are challenged through language. By trying to qualify their intimate relationships, interviewees creatively re-work the traditional meanings of the family to widen them and to make room for their experience ( $\mathrm{Gabb}$ 2005). The family (and what follows in terms of heteronormativity, gender roles, 
etcetera) remains a cultural reference, but the narrative of the interviewees allows some shifts of meaning. For example, Gaia describes as non-familial the relationship they (her, her partner and the donor friend) want to create and as a "nonpaternity relationship' the one she and her partner envisage between their future child and the donor.

G: Then we identify a donor, a friend that for various reasons was perfect and was willing to be part of the reproductive process but also was willing to gamble with us on the possibility of forms of non familial relationships, but sentimental relationships...i don't know how to explain it... he was, in principle at least, willing to create a relation of non-paternity with the newborn...

R: What do you mean by non paternity?

G: Not being a father from the legal point of view, hence not recognising (legally, the child), not taking on him the duties and honours of the role, and then being a male figure in the emotive universe of the boy or the girl that though does not imply being a father. Now like... I am going to say the nearest thing I can imagine in my stereotyped universe, like an uncle, but then he might not be an uncle and we might want to call thingumabob and it means whatever will grow out of (the interaction) between the two of them... (Gaia, 41)

A similar situation occurs in the story of Stefano and his partner, a gay foster couple.

We do not feel the necessity to introduce ourselves... we arrive, that is what we are. Me and him, me, him and the boy [...] My partner once said to a guy who lived next door and wanted to visit us: "Yes, I will be delighted (if you visit us), so you will meet my family, my (male) partner and our affiglio" we coined this term affiglio, that comes from affido (foster) and figlio (son). (Stefano, 49)

Stefano explicitly uses language to challenge their invisibility. By using the word 'affiglio' Stefano challenges the trope of "as if we were a couple and parents like the others" (Cadoret 2008) and forces the boundaries of kinship to make room for their specific intimate relationships. A similar naming practices is narrated by Chiara while describing the way her two children call her and her partner:

They call me mamma obviously. In a very spontaneous way, because I am always here.... I live here... and consequently... mamma... they also call me babba... This is something I am really proud of... it happened because of a bad cold they caught last winter... They could not say mamma... it came out as babba. I loved it so much that I insisted on babba and now when they have to distinguish us they say mamma and babba... I think that babba really breaks every prejudice... (Chiara, 40)

'Babbo' is a regional variant of 'papà (father)', here the word is re-gendered to accommodate Chiara as social mother. In a context that not only excludes parenting from legal recognition but also vociferously denies their very existence in the public sphere, the practices of naming and defining appear central in the narratives of some of the families and families-to-be. These narratives do not displace dyadic and differentiated form of parenting but do challenge the boundaries of kinship lexicon impacting a societal discourse that exclude them. 


\subsubsection{Love Is All You Need?}

In other respondent's stories, mutual love and commitment emerge as key symbolic resources to account for their experience and define themselves as 'legitimate' families. Emblematic is the story of Enrica who at the time of the interview had been with her partner Roberta for 9 and a half years, got married in a North European Country 2 years before and had two children. As in many other narratives, the story of their couple and their family develops as a sequence of events that naturally arises from love, passes through cohabitation and finds their successful completion in the birth of their two children. The way Enrica narrates the couple's decision of becoming mothers is particularly interesting:

E: After few time she expressed the wish to have children. For what concerns me.... Actually it wasn't an existential need, I never felt I would have been incomplete as a woman if I wouldn't have had children. Neither did she, however something resounded inside her. She always tells me that she thinks I am the person that made her feel capable to carry on such a life project. Honestly, I would have never had children with anyone else.

R: Why you say that?

E: I have many girlfriends that at some point felt the need to becoming mothers, and this is totally respectable. But for me it was a project... something that grew with her and even if I had many relationships before, this idea (of having children) never arose before. I like her as a mother, as a parent, how we are able to combine each other with our very different characteristics... and our children are the way in which we reaped the fruits of our love. (Enrica, 44)

Enrica's narrative of the decisions that lead to her and her partner's pregnancies resonates profoundly with the 'self-reflective' project ideal (Giddens 1992) that is envisaged as free of constraints and presents itself as rejecting any gendered expectations. She has a twofold trajectory in her story: on one side, she explicitly positions her parenting project out of the traditional and naturalizing narrative of procreative female roles and underlines twice that she doesn't feel that having children is what defines her identity as a woman. On the other, the ideal of the modern democratic monogamous couple defined by love is dominant in her narrative. The refusal of a normative gendered role is counterbalanced by the love that becomes generative of both the desire to have children and the act of having children. In doing so however, her narrative still maintains procreation as the ultimate goal of the monogamous couple. A couple that she narrates following the script of complementary roles.

We are really interchangeable... but for reasons that have to do with our personalities. I am much more 'homely' and Roberta is much more 'outdoorsy'. She is always outdoor, on the bike, running... and eventually, we realised that the children ended up identifying a Mother Home and a Mother Play... I am more Mother Home and Roberta is more Mother Play... even though the girls stay home also with Roberta and play also with me the one they get really crazy with is Roberta... And with me... I don't know, we bake cakes together, biscuits for Christmas, we decorate the Christmas tree... but for instance, we both help Mirella with her homework... since I work from home more often, I am more... maybe I do the daily shopping. Also, I love cooking, so it is natural for me to take care of lunches and 
dinners. However, on Sunday night is usually Roberta who cooks dinner... she cooks crêpes for everyone and... and that is the exception to the rule... we eat while watching a movie.... (Enrica, 44)

The 'mother-home' vs. 'mother-play' narrative resonates with a differentiation between a caring homely role and a more social outdoor role but in doing so disrupts its gendered assumptions. Enrica explains the division of roles within the parenting couple as the results of an organic encounter between hers and her partner's 'natural' inclinations and the children's desires. Gay and lesbian couples challenge de facto the assumptions that sexual complementarity mirrors sentimental complementarity and, above all, generative complementarity that guides traditional notions of couple and kinship (Cadoret 2008). Enrica's narrative, however, is tied to the heteronormative repertoire of a difference (between the partners) that is essentials to meet the children's need. As in Ryan-Flood's analysis, also in the case of our interviewees, we can see a tension whereby lesbian mothers seek to both repudiate and affirm heteronormative discourses that generate from their location and contexts and "are both constituted through and resisting of particular narratives of kinship" (2005: 201).

The tension between constitution and resistance is clear also in Enrica's discussion about both pregnancies, the role of the sperm donor and the subsequent negotiation of his parental roles. Enrica and his wife choose a friend as sperm donor, who was unwilling to play a parental role within the life of the newborns. While he pays yearly visits, he does not have any parent-like or relative-like relationship with their daughters.

We knew we did not want a project shared by four people. We always wanted to be the two mothers of our two children. [...] At one point we had this desire to... it became a really strong desire to not leave Mirella alone! We liked the idea of a brother or a sister for her [...] this time... I mean the second time I tried and I got pregnant really fast. (Enrica, 44)

He was the donor for both pregnancies as a way to create a biological connection between siblings. In this decision, it is possible to trace a tension between the desire to conform to a normative/biologically informed ideal of the family and the desire to disrupt the dominance of blood ties. Enrica's narrative does not contemplate alternatives to the dual parenting couple but, at the same time, acknowledges that there is the possibility of a 'natural' desires of their children to know their biological roots. Hence the decision for a known donor. The biological/natural trope became central in Enrica's narrative around the use of a single sperm donor for both pregnancies. Somehow the biological link, subverted in the case of the parenting relationship, is maintained to solidify the relationship between siblings. In Enrica's narration of the decisions that led to the second pregnancy, it is possible, once again, to see the dominance of the trope of love free of constraints. Enrica refers to the 'child interest'. In her narrative is central the desire not to leave their first child alone but there is no explicit reference to her position with regard to Roberta, the legally recognised parent of their first daughter. While this is acknowledged later, it is not expressed as the reason why a second pregnancy was planned. The dominance of a narrative organised around love does not leave space for acknowledging power dynamics in the dyadic couple- and in particular how the lack of legal recognition 
can impact the relationship. The family is narrated as a harmonious, conflict-free realm. By mobilising heteronormative narratives Enrica displays normativity as a desirable/comfortable place to be (Ahmed 2004: 147). Enrica's narrative is shared by other participants that equally construct the parenting project as connected to love and the fulfilment of the couple.

Unlike Enrica, Benedetta put forward a different narrative; while still relying on tropes of love and monogamous coupledom, her narrative underlines several times the problematic features of this process. A social mother-to-be, Benedetta is also thinking about getting pregnant herself, after her partner, but her narrative does not revolve around the desire to give birth as a woman nor around the desire to complete/complement the couple-project.

Because I intend to... next summer maybe... or maybe next autumn.. to try but... but I really do not have this pregnancy thing... I'd do it only to create a familial bond on both sides. Between me and the child my partner is carrying and between her and a child I could potentially carry ... so that... I mean, I do not know... I fantasise that this will prevent a possible break-up... what I mean is [it will prevent that one of us is] stronger than the other. But I mean... unfortunately when you are $40 \ldots$ because I had relationships before her, really committed relationships that I never thought would ever end... even now that they are over I realise how I imagined them to last forever. (Benedetta, 38)

Central to Benedetta's narrative is the need to solidify the ties among her, her partner and their future child by complicating them, legally and emotionally. In Benedetta's narrative, the complexities of the parenting project and the lack of legal recognition to parenting are revealed and made explicit. A space is created to complicate the trope of love until death do us part. In so doing the power dynamics between the parent who is legally recognised and the one who isn't and their families of origin are also recognised. In the above, the impact of social and legal structures became apparent and difficult to escape, as it becomes evident how they might shape or have shaped the decisions of our respondents.

\subsubsection{The Context-Dependent Challenge of Heteronormativity: The Role of Legal Constraints}

The narratives analysed so far highlighted the tension between the comfort and discomfort with the heteronormative script and the ways families negotiate dominant meanings of family and coupledom. As discussed above, the Italian context is dominated not only by the trope of the 'natural family' in public discourses, but also by the absence of legal recognition. Besides the absence of recognition of the social parents, access to ART is denied to single women and lesbian couples, surrogacy is prohibited, and adoption is open to married heterosexual couples only. These legal constraints force LGB couples to travel abroad in order to conceive their children. 
Lack of a legal framework for same-sex parents, therefore, influences the range of material options available to gay and lesbian couples as Silvia points out:

I don't want to run the risk that, at some point, someone shows up and says "Since we are genetically tied, he is my son" ... The Italian law allows this. (...) This means that even a (donor) friend is risky. If we had a legal recognition of parenting rights, I would not have had any problem (...) but as it is not so, it is way too risky, especially for the parent that is not legally recognised. (Silvia, 41)

The choice of recurring to ART abroad with an unknown donor and to retain the parental roles within the lesbian couple rather than an act of conforming to the dyadic heteronormative model of parenting and coupledom is here framed a 'bounded choice' resulting from the lack of sexual citizenship rights. In reading these narratives it is crucial to reflect on the constraints of the context in which they are produced and reflect on the role the heteronormative script plays in granting LG couples' cultural intelligibility (Butler 1990).

Cultural intelligibility is a disciplinary regime that strictly defines the symbolic resources available to individuals to perform their identity and a normative framework that defines the social field where identities can have a legitimate expression. Such a framework conditions who can be considered as a legitimate (and recognizable) subject. The necessity of being culturally intelligible becomes crucial when advancing claims for legal recognition of parenting rights to juvenile law courts. As discussed above, given the absence of a national law, Italian same-sex parents have appealed to law courts since 2015 to be granted parenting rights:

The lawyer explained to me that (the result of the claim) really depends upon which Court (will examine your case), however, even in the case of a court willing to examine your case (of a step-child adoption) you have to demonstrate that your cohabitation dates back five, six years, that the child recognise you as... that he or she spent (with you) Christmas, the summer holidays (...) so, if in five, six years there still won't be a law, then we can try the step-child adoption, in the meantime we collect Christmas Cards, letters, home movies, as other couples told me (they are doing)... (Gaia, 41)

Christmas cards, home movies, and proof of a stable cohabitation materialise the couple's cultural intelligibility and become markers of a familial project worthy of recognition. The strategies of the Rainbow Families movement resonate in Gaia's narrative as the possibility to strategically adhere to normativity in order to pursue one's aim. As Benedetta discusses, this strategy is a response to the precariousness of the process of recognition. At the time of the interview, only one couple had been successfully through the process of step-child adoption; while at the time of writing several couples have been successfully through it, the process of scrutiny by Juvenile courts remains the same. Successful outcomes are framed as linked to the ability to demonstrate, during the trial, the couple stability, cohabitation and parenting longterm project as key prerequisite to be recognised as a 'good' (and worthy of recognition) family: 
Because the deal is this... there is no blueprint, they are making it up... the Rainbow Families association is helping us by saying that, statistically, it works to collect as many documents as possible [demonstrating] the existence of a shared familial project... from the pictures in the labour unit... in the clinic... both signatures [should appear] on every document. We both signed every document. When he will be born... for the nursery [the association suggests] that we ask to be both included in every documents. Because the only couple that managed... we are talking only about one sentence that might eventually be challenged... the couple followed this path... the consolidamento familiare (family stabilisation)... And they demonstrated the familial project, the family, the affective and economic ties... within the couple and between the non-biological mother and her daughter. (Benedetta, 38)

Requests for the legal recognition of same-sex couples, whether in the form of gay marriage or same-sex partnership, have been criticised as upholding values that replicate the discursive structures that reifies heterosexual family and kinship (Butler 2002: 21). The legal recognition of same-sex couples, as well as the debate on gay marriage, are framed as shifting the boundaries of acceptance to the stable monogamous couple, reaffirming the exclusion of queer sexualities (Butler 2002: 17; Bell and Binnie 2000). The forms of kinship that remain unnamed or do not respond to the possibility of legitimation, become in turn unintelligible (Butler 2000, 2002). The process of legitimation is in the State's own terms and to agree to it requires to abide by its lexicon and norms. However, cultural intelligibility has very material consequences in contemporary Italy. Not to participate in it comes at a cost of not being legally recognised in a context characterised by a strong familial welfare. Within this framework, gathering 'evidences' of being a 'proper family' rather than being defined as an homonormative move that solidify dominant discourses on family and kinship, could be interpreted as a "contextual challenge to heteronormativity' (Ryan-flood 2005) that strategically manipulates the cultural and social resources available in order to claim citizenship rights.

\subsection{Conclusion}

LGB parents in Italy negotiate a societal context that, while more accepting of same-sex relationships (ISTAT 2012), keeps considering same sex parents unthinkable (Lingiardi 2013). The unthinkability of LGB parents, it has been argued, derives from a perceived misalignment of gender, generativity and parenting (Ferrari 2015) and is then reflected on and amplified by the lack of full access to citizenship rights. As discussed in the introduction, while a law has now recognised partnership rights, parenting rights are still denied to the parent who has no biological bond with the child(ren), a law on homophobia as aggravating circumstance in hate crimes is still missing, and access to ART is denied to lesbian couples and single women. Moreover, Italy is currently experiencing a strong backlash against minoritized groups. The frequent attacks on women and LGBT rights are exposing families that do not conform to the heteronorm, to homophobic violence in the public sphere 
(Garbagnoli and Prearo 2018). Against the discursive violence of right wing politics and part of the Catholic Church, however, an increasing number of court cases have been recognising parenting rights to non-biological parents, de facto bypassing the Government's lack of action.

In this conflicting scenario, characterised by increasing institutional homophobia as well as support from the judicial power, gay men and lesbian women organise their intimate lives and manipulate the limits and resources of the Italian context. As the analysis conducted above has shown interviewees employ a set of different strategies to account for their familial and kinship relationships and to have those recognised by society.

These strategies sit often in an ambivalent space that both challenges and reifies the couple norm and the heteronormative model of kinship construction. Naming practices acknowledge roles that are not contemplated in public discourses such as that of a donor, a social mother, or a foster parent. On one side, gay and lesbian parents manipulate the lexicon of heteronormative kinship and in so doing they performatively create a new set of words that contribute to making a lesbian mother or a gay father as thinkable. On the other side, however, the lexicon of heterosexual kinship is hard to be displaced; even those experiences that aim to challenge the heterosexual family structure continue to use it as their reference point. Challenges to the dyadic couple still allude to a conventional family lexicon to define the affective and caring relationships that different adults might have with a child. Similarly, the trope of love and complementary care roles resound in our respondents' narratives. The dyadic parenting couple is rarely questioned as the starting point of parenting and love - conflict and power-free - is evoked as the generative device of the family.

At this stage, however, the tension between normativity and disruption appears to be an insufficient framework to account for the interviewees' experiences. From a certain perspective they seem to adhere to a homonormative ideal of coupledom and parenting that reproduces traditional kinship models and ideals. However, once we take into account the Italian context, these narratives reveal a strategic adherence to norms. They unravel how hegemonic norms govern cultural intelligibility of couple and kinship relationships. In a context of lack of basic parental rights and conservative beliefs around gender, sexuality and the family, adherence to the narrative of a 'proper' family appears to be strategic. In fact, it can be a way to gain access to social recognition and as in the case of court hearings, to legal recognition of one's parenting rights.

As some narratives showed, families seem to perform a strategic use of the heteronormative repertoire in order to challenge the material legal constraints and claim for sexual citizenship rights. In light of the collected narratives, we suggest thinking beyond the dichotomy of assimilation or resistance to heteronormativity and homonormativity and instead paying attention to the multiple and varied ways in which gay and lesbian parents' strategically manipulate the norms that are excluding them. 


\section{Appendixes}

\section{Appendix 1: Participants}

\begin{tabular}{|c|c|c|c|c|c|c|}
\hline & Pseudonym & Sex & Age & $\begin{array}{l}\text { Couple } \\
\text { Status }\end{array}$ & Parental Status & Geography \\
\hline 1 & Carlo & Male & 46 & LAT & No children & North - City \\
\hline 2 & Gaia & Female & 41 & Cohabitation & $\begin{array}{l}\text { Going through ART at the time } \\
\text { of the interview }\end{array}$ & North - City \\
\hline 3 & Alessandra & Female & 36 & Cohabitation & No children & North - City \\
\hline 4 & Silvia & Female & 40 & Cohabitation & No children & North - City \\
\hline 5 & Lara & Female & 36 & Cohabitation & No children & North - City \\
\hline 6 & Cristina & Female & 51 & Cohabitation & $\begin{array}{l}1 \text { child, previous heterosexual } \\
\text { relationship }\end{array}$ & North - City \\
\hline 7 & Ernesto & Male & 60 & Cohabitation & 2 children, through surrogacy & North - City \\
\hline 8 & Marco & Male & 40 & Cohabitation & No children & North - City \\
\hline 9 & Enrica & Female & 44 & Cohabitation & $\begin{array}{l}2 \text { children, through } \\
\text { self-insemination }\end{array}$ & North - City \\
\hline 10 & Silvio & Male & 62 & Cohabitation & No children & North - City \\
\hline 11 & Maurizio & Male & 52 & Cohabitation & $\begin{array}{l}2 \text { children, previous heterosexual } \\
\text { relationship }\end{array}$ & North - City \\
\hline 12 & Daniele & Female & 45 & \multirow[t]{2}{*}{ Cohabitation } & \multirow[t]{2}{*}{ No children } & \multirow[t]{2}{*}{ South - City } \\
\hline 13 & Andrea & Female & 43 & & & \\
\hline 14 & Giorgia & Female & 38 & \multirow[t]{2}{*}{ Cohabitation } & \multirow[t]{2}{*}{1 child through ART } & \multirow[t]{2}{*}{ South - City } \\
\hline 15 & Tiziana & Female & 36 & & & \\
\hline 16 & Flavia & Female & 60 & Cohabitation & $\begin{array}{l}2 \text { children, previous hetero } \\
\text { relation }\end{array}$ & South - City \\
\hline 17 & Anna & Female & 46 & Cohabitation & No children & South - City \\
\hline 18 & Irene & Female & 22 & LAT & No children & South - City \\
\hline 19 & Francesco & Male & 32 & Cohabitation & No children & South - City \\
\hline 20 & Domenico & Male & 46 & LAT & No children & South - City \\
\hline 21 & Giorgio & Male & 28 & Cohabitation & No children & South - City \\
\hline 22 & Benedetta & Female & 38 & LAT & $\begin{array}{l}\text { Her partner was pregnant at the } \\
\text { moment of interview }\end{array}$ & South - City \\
\hline 23 & Maria & Female & 34 & \multirow[t]{2}{*}{ Cohabitation } & \multirow{2}{*}{$\begin{array}{l}\text { Going through ART at the time } \\
\text { of the interview }\end{array}$} & \multirow[t]{2}{*}{ North - City } \\
\hline 24 & Elisabetta & Female & 34 & & & \\
\hline 25 & Amanda & Female & 38 & \multirow[t]{2}{*}{ Cohabitation } & \multirow[t]{2}{*}{1 child through ART } & \multirow[t]{2}{*}{ North - City } \\
\hline 26 & Isabella & Female & 37 & & & \\
\hline 27 & Serena & Female & 36 & Cohabitation & $\begin{array}{l}\text { Pregnant at the moment of } \\
\text { interview }\end{array}$ & North - City \\
\hline 28 & Donatella & Female & 46 & LAT & $\begin{array}{l}2 \text { children, previous heterosexual } \\
\text { relationship }\end{array}$ & North - City \\
\hline 29 & Chiara & Female & 40 & \multirow[t]{2}{*}{ Cohabitation } & \multirow[t]{2}{*}{2 children through ART } & \multirow[t]{2}{*}{ North - City } \\
\hline 30 & Valeria & Female & 40 & & & \\
\hline
\end{tabular}




\begin{tabular}{l|l|l|l|l|l|l}
\hline & Pseudonym & Sex & Age & $\begin{array}{l}\text { Couple } \\
\text { Status }\end{array}$ & Parental Status & Geography \\
\hline 31 & Tommaso & Male & 45 & Cohabitation & $\begin{array}{l}\text { 2 children, previous heterosexual } \\
\text { relationship }\end{array}$ & South - City \\
\cline { 3 - 4 } 32 & Elia & Male & 55 & & & \\
\hline 33 & Riccardo & Male & 59 & Cohabitation & No children & South - City \\
\hline 34 & Luigi & Male & 54 & & & South - City \\
\hline 35 & Stefano & Male & 49 & Cohabitation & 1 child in foster care & North - City \\
\hline 36 & Fulvio & Male & 56 & Cohabitation & No children &
\end{tabular}

\section{Appendix 2: Interview Outline}

After the first generative question, all others were asked only if the interviewee(s) didn't mention the theme autonomously.

\section{Generative Question}

Can you tell me the story of your current relationship?

(explore both genealogy and actual situation)

\section{SECTION 1 - VISIBILITY}

1. Are there contexts where you are not visible as partnered in a same sex relationship? (i.e. work, university, family of origin, friends, landlord, etcetera). If yes, can you tell me in which ones and why? Is it a joint choice with your partner or not? How do you manage it?

2. Concerning the family of origin:

- Can you tell me about the last family celebration?

3. Concerning the workplace:

- Do you take part in work events when partners are invited?

- Do you usually tell colleagues about your holidays?

- Do you have pictures of your partner and/ or your children on your desk/ at the workplace?

4. Have you ever been discriminated against for being in a same-sex relationship?

- If yes, can you tell me what happened? 
5. Do you think that being visible in a same-sex relationship exposes you differently to discrimination or homophobia?

\section{SECTION 2 - COUPLE AND MARRIAGE}

6. Have you symbolically celebrated your union? (i.e. a ritual, a party, etcetera)

- If yes, can you tell me how it went? Were your families of origin invited and/or involved in the organization?

- If no, do you think you will celebrate one day? How do you wish it will be?

7. Do you think that the legal recognition of your union will change your daily life?

- If yes, how? If no, why? (investigate both the symbolic level - as the public recognition - and the material level - as the taxation, access to public services, etcetera.)

8. Which legal form should this recognition have? (i.e equal marriage, civil unions, registered partnership, etcetera). Why it should have this specific form of recognition?

9. Do you think that the legal recognition of same-sex unions would counteract homophobia and discrimination?

10. Do you think that a law against homophobia would change the quality and safety of your life? How?

- Which rights should the law protect?

- If no, why it wouldn't change it?

\section{SECTION 3 - CHILDREN AND FAMILY LIFE.}

11. How many children do you have? How old are they?

12. How and when did you decide to have children? [for those interviewees who have (or are having) children within the couple]

13. How did you decide to have children? (i.e. ART, self-insemination, surrogacy, adoption, co-parenting, etcetera).

- Why did you choose this way over others?

- Did you tell your family of origin about the decision of having children? Did it change your relationship with them? If yes, how?

14. What changed in your life when you became a parent? Explore the relationship with the families of origin, the workplace (parental leave, visibility, work-life balance) and within the couple (negotiation of care roles). 
15. Did you feel supported beyond the couple? I.e. kinship networks, friends' networks.

16. Can you tell me about your experiences with public services as same sex parents

- the first pediatrician appointment?

- the enrolment to pre-school/school?

17. Has your child(ren) ever been discriminated for having same-sex parents?

- If yes, can you tell me what happened? What did you do?

- If not, are you worried it could happen in the future? What would you do in such a situation?

18. Did you decide how to deal with potential negative events as a break-up or death? (i.e. private agreements, will, etcetera).

\section{References}

Ahmed, S. (2004). The cultural politics of emotion. Edinburgh: Edinburgh University Press.

Beck-Gernsheim, E. (1998). On the way to a post-familial family: From a community of need to elective affinities. Theory, Culture \& Society, 15(3-4), 53-70.

Beck, U., \& Beck-Gernsheim, E. (1995). The normal chaos of love. Oxford: Polity Press.

Bell, D., \& Binnie, J. (2000). The sexual citizen: Queer politics and beyond. Cambridge: Polity Press.

Bertone, C. (2009a). Le omosessualità. Roma: Carocci.

Bertone, C. (2009b). Una sfida a quale famiglia? Comprendere i mutamenti familiari attraverso le esperienze dei genitori non eterosessuali. In C. Cavina \& D. Danna (Eds.), Crescere in famiglie omogenitoriali. Milano: Franco Angeli.

Bertone, C. (2015). Il fascino discreto delle famiglie omogenitoriali. Dilemmi e responsabilità della ricerca. Cambio, 5(9), 37-45.

Bertone, C., \& Gusmano, B. (2013). Queerying the public administration in Italy: Local challenges to a national standstill. In Y. Taylor \& M. Addison (Eds.), Queer presences and absences (pp. 260-278). London: Palgrave Macmillan.

Bruner, J. (1996). A narrative model of self construction. Psyke \& Logos, 17(1), 154-170.

Butler, J. (1990). Gender trouble: Feminism and the subversion of identity. New York/London: Routledge.

Butler, J. (2000). Antigone's claim: Kinship between life and death. New York: Columbia University Press.

Butler, J. (2002). Is kinship always already heterosexual? Differences, 13(1), 14-34.

Cadoret, A. (2008). Genitori come gli altri: omosessualità e genitorialità. Milano: Feltrinelli.

Crowhurst, I., \& Bertone, C. (2012). Introduction: The politics of sexuality in contemporary Italy. Modern Italy, 17(4), 1-6.

Donà, A. (2009). From Pacs to Didore: Why are civil partnership such a divisive issue in Italian politics? Bulletin of Italian Politics, 1(2), 333-346. 
Duggan, L. (2003). The twilight of equality? Neoliberalism, cultural politics, and the attack on democracy. Boston, MA: Beacon Press.

Farina, M. (2017). Same-sex adoptions: The Italian case. The Italian Law Journal, 3, 207-220.

Fassin, E. (2001). Same sex, different politics: "Gay marriage" debates in France and the United States. Public Culture, 13(2), 215-232.

Ferrari, F. (2015). La famiglia inattesa. Milano: Mimesis.

Franchi, M., \& Selmi, G. (2018). Challenging the unthinkable: Gay and lesbian parents between redefinition and exclusion in Italy. AG About Gender-Rivista internazionale di studi di genere, $7(14), 1-21$.

Gabb, J. (2005). Lesbian M/otherhood. Strategies of familial-linguistic Management in Lesbian Parent Families. Sociology, 39(4), 585-603.

Gabb, J. (2008). Researching intimacy in families. Basingstoke: Palgrave Macmillan.

Gamson, J., \& Moon, D. (2004). The sociology of sexualities: Queer and beyond. Annual Review of Sociology, 20, 47-64.

Garbagnoli, S. (2014). 'L'ideologia Del Genere': L'irresistibile Ascesa Di Un'invenzione Retorica Vaticana Contro La Denaturalizzazione Dell'ordine Sessuale. AG About Gender, 3(6), 250-263.

Garbagnoli, S., \& Prearo, M. (2018). La crociata "anti-gender". Dal Vaticano alle manif pour tous. Torino: Kaplan.

Giddens, A. (1992). The transformation of intimacy: Sexuality, love and eroticism in modern societies. Oxford: Polity Press.

Gross, N. (2005). The detraditionalization of intimacy reconsidered. Sociological Theory, 23(3), 286-311.

Hey, V. (2005). The contrasting social logics of sociality and survival: Cultures of classed be/longing in late modernity. Sociology, 39(5), 855-872.

ISTAT. (2012). La popolazione omosessuale in Italia. In Statistiche report. Roma: ISTAT.

Jamieson, L. (1998). Intimacy: Personal relationships in modern societies. Cambridge: Polity Press.

Lasio, D., \& Serri, F. (2017). The Italian public debate on same-sex civil unions and gay and lesbian parenting, Sexualities, online version.

Lingiardi, V. (2013). La famiglia inconcepibile. Infanzia e adolescenza, 12(2), 74-85.

Mancina, C., \& Vassallo, N. (2016). Unioni civili? Un dialogo sulla legge approvata dal Parlamento italiano. Iride, 29(79), 551-564.

Plummer, K. (1995). Telling sexual stories: Power, change, and social worlds. London/New York: Routledge.

Plummer, K. (2003). Intimate citizenship: Private decisions and public dialogues. Montréal: McGill-Queen's University Press.

Richardson, D., \& Monro, S. (2012). Sexuality, equality and diversity. Basingstoke: Palgrave Macmillan.

Riessman, C. K. (2008). Narrative methods for the human sciences. London: Sage.

Roseneil, S., Crowhurst, I., Santos, C., \& Stoilova, M. (2013). Reproduction and citizenship/reproducing citizens: Editorial introduction. Citizenship Studies, 17(8), 901-911.

Rosenfeld, D. (2009). Heteronormativity and homonormativity as practical and moral resources: The case of lesbian and gay elders. Gender \& Society, 23(5), 617-638.

Rosina, A., \& Viazzo, P. (2008). Oltre le mura domestiche: famiglia e legami intergenerazionali dall'unità d'Italia ad oggi. Udine: Forum.

Ruspini, E. (2005). Il silenzio e la parola. In E. Ruspini (Ed.), Donne e uomini che cambiano (pp. 11-36). Milano: Guerini.

Ruspini, E. (2009). "Italian forms of masculinity between Familism and social change." in. Culture, Society \& Masculinities, 1(2), 121-136.

Ryan-Flood, R. (2005). Contested Heteronormativities: Discourses of fatherhood among lesbian parents in Sweden and Ireland. Sexualities, 8(2), 189-204.

Saraceno, C. (2012). Coppie e famiglie. Non è questione di natura. Milano: Feltrinelli. 
Selmi, G. (2015). Chi ha paura della libertà? La così detta ideologia del gender sui banchi di scuola. AG About Gender-Rivista internazionale di studi di genere, 4(7), 263-268.

Skeggs, B. (2004). Class, self, culture. London: Routledge.

Somers, M. R., \& Gibson, G. D. (1994). Reclaiming the epistemological "other": Narrative and the social constitution of identity. In C. Calhoun (Ed.), Social theory and the politics of identity (pp. 35-99). Oxford: Blackwell.

Trappolin, L. (2009). Lotte Per Il Riconoscimento E Ruolo Dei Mass-Media. I Significati Del "Gay Pride". Partecipazione e conflitto, 1, 123-145.

Weeks, J. (1998). The sexual citizen. Theory Culture and Society, 15(3), 35-52.

Weeks, J., Heaphy, B., \& Donovan, C. (2001). Same sex intimacies: Families of choice and other life experiments. London: Routledge.

Open Access This chapter is licensed under the terms of the Creative Commons Attribution 4.0 International License (http://creativecommons.org/licenses/by/4.0/), which permits use, sharing, adaptation, distribution and reproduction in any medium or format, as long as you give appropriate credit to the original author(s) and the source, provide a link to the Creative Commons licence and indicate if changes were made.

The images or other third party material in this chapter are included in the chapter's Creative Commons licence, unless indicated otherwise in a credit line to the material. If material is not included in the chapter's Creative Commons licence and your intended use is not permitted by statutory regulation or exceeds the permitted use, you will need to obtain permission directly from the copyright holder. 